\title{
Analisis sub sektor perkebunan Provinsi Jambi
}

\author{
Popi Fitriandi*; Hardiani; Candra Mustika \\ Prodi Ekonomi Pembangunan, Fak. Ekonomi dan Bisnis, Universitas Jambi \\ *E-mail korespondensi:popi_fitriandi@yahoo.com
}

\begin{abstract}
The purpose of this research is first, to know and analyze the development of the land area, labor, and GRDP of the plantation sub-sector in Jambi Province. Second, knowing and analyzing the contribution of the plantation sub-sector to the agricultural sector and the GRDP of Jambi Province. Third, to analyze the effect of land area and labor on the output of the plantation sub-sector in Jambi Province. The development of the land area, labor, GDP in the plantation sub-sector of Jambi Province for the period 2000-2015 continued to increase, with an average increase in land area of 2.52\%, a workforce of $2.74 \%$, GRDP of the plantation sub-sector by $7.84 \%$. The contribution of the plantation sub-sector to the agricultural sector and the GRDP of Jambi Province for the period 2000-2015 also continued to increase. Based on the results of multiple linear regression calculations, simultaneously land area and labor have a significant effect on the output of the plantation sub-sector in Jambi Province. Partially, land area has a significant effect on the output of the plantation sub-sector in Jambi Province, while labor does not affect the output of the plantation sub-sector in Jambi Province.
\end{abstract}

Keywords: Land area, Labor, Gross regional domestic product of plantation sub sector

\begin{abstract}
Abstrak
Adapun tujuan dari penelitian ini pertama, mengetahui dan menganalisis perkembangan luas lahan, tenaga kerja, dan PDRB sub sektor perkebunan di Provinsi Jambi. Kedua, mengetahui dan menganalisis kontribusi sub sektor perkebunan terhadap sektor pertanian dan PDRB Provinsi Jambi. Ketiga, menganalisis pengaruh luas lahan dan tenaga kerja terhadap output sub sektor perkebunan Provinsi Jambi. Perkembangan luas lahan, tenaga kerja, PDRB sub sektor perkebunan Provinsi Jambi periode 2000-2015 terus mengalami peningkatan, dengan rata-rata peningkatan luas lahan sebesar 2,52 \%, tenaga kerja 2,74 \%, PDRB sub sektor perkebunan sebesar 7,84\%. Kontribusi sub sektor perkebunan terhadap sektor pertanian dan PDRB Provinsi Jambi periode 20002015 juga terus mengalami peningkatan. Berdasarkan hasil perhitungan regresi linear berganda, secara simultan luas lahan dan tenaga kerja berpengaruh signifikan terhadap output sub sektor perkebunan Provinsi Jambi. Secara parsial luas lahan berpengaruh signifikan terhadap Output sub sektor perkebunan Provinsi Jambi, sedangkan tenaga kerja tidak berpengaruh terhadap output sub sektor perkebunan Provinsi Jambi.
\end{abstract}

\footnotetext{
Kata kunci: Luas lahan, Tenaga kerja, Produk domestik regional bruto sub sector perkebunan
}

\section{PENDAHULUAN}

Pertanian adalah suatu kegiatan manusia dalam memanfaatkan sumber daya hayati untuk dapat menghasilkan bahan pangan, sumber energi, bahan baku industri dan untuk mengelola lingkungannya. Itulah arti dari pertanian secara umum. Pengertian pertanian 
menurut Anwas (1992: 34) adalah kegiatan manusia mengusahakan terus dengan maksud memperoleh hasil-hasil tanaman ataupun hasil hewan, tanpa mengakibatkan kerusakan alam.

Sektor pertanian sebagai salah satu sektor penyumbang terbesar dalam Produk Domestik Ragional Bruto (PDRB) dan diharapkan akan dapat mendorong kegiatan perekonomian industri. Hal ini tersebut terlihat dari sumbangan atau kontribusi sektor pertanian pada pembangunan ekonomi yang cukup besar terutama dalam penyediaan surplus pangan pada penduduk yang makin meningkat, penyediaan akan bahan baku industri, tambahan penghasilan devisa dari ekspor produk pertanian, peningkatan pendapatan daerah dan memperbaiki kesejahteraan rakyat khususnya pedesaan (Jhingan, 1993).

Perkebunan adalah segala kegiatan yang mengusahakan tanaman tertentu pada tanah dan/atau media tumbuh lainnya dalam ekosistem yang sesuai, mengolah dan memasarkan barang dan jasa hasil tanaman tersebut, dengan bantuan ilmu pengetahuan dan teknologi, permodalan serta manajemen untuk mewujudkan kesejahteraan bagi pelaku usaha perkebunan dan masyarakat (Badan Pusat Statistik 2011).

Perkebunan merupakan salah satu sub sektor pertanian yang penting dalam struktur perekonomian saat ini, juga sebagai mata rantai dalam dunia usaha yang utama, perkebunan sangat memberi arti yang penting dalam pembangunan serta pertumbuhan ekonomi masyarakat. Arah pembangunan sub sektor perkebunan seperti yang telah ditetapkan oleh Direktorat Jendral Bina Produksi Perkebunan adalah mewujudkan perkebunan yang efisien, produktif dan bersaing tinggi untuk kemakmuran rakyat secara berkeadilan dan berkesinambungan. Program pembangunan perkebunan yaitu melaksanakan pengembangan agribisnis yang berbasis komoditas dan menciptakan ketahanan pangan.

Sub sektor perkebunan merupakan salah satu sub sektor sebagai komponen dari sektor pertanian, sub sektor perkebunan tidak kalah pentingnya dari sub sektor-sub sektor lain pada sektor pertanian sebagai pembentuk PDRB. Berbagai komoditi yang dihasilkan oleh sub sektor perkebunan, seperti karet, kelapa sawit, kelapa dalam, kulit kayumanis, kopi robusa dan lain sebagainya merupakan komoditi-komoditi yang dijadikan sebagai bahan baku industri dan diterima di pasar internasional. Sub sektor perkebunan juga merupakan sub sektor pertanian yang secara tradisional merupakan salah satu penghasil devisa negara. Sebagian besar tanaman perkebunan tersebut merupakan usaha perkebunan rakyat, sedangkan sisanya diusahakan oleh perkebunan besar baik milik pemerintah maupun milik swasta (Soetrisno L. 1999).

Selain mempunyai kontribusi terhadap produksi nasional, Provinsi Jambi juga memberikan kontribusi terhadap ekspor nasional. Sub Sektor perkebunan merupakan salah satu andalan dalam perekonomian Provinsi Jambi. Kontribusi sub sektor perkebunan terhadap sektor pertanian dalam kurun waktu 2013-2015 tergolong besar. Rata-rata kontribusi sub sektor perkebunan tercatat sebesar 48 persen. Sementara ratarata kontribusi sub sektor perkebunan terhadap PDRB Provinsi Jambi sebesar 15,60 persen kurun waktu 2013-2015 .

Salah salah satu faktor penting penentu output sub sektor perkebunan adalah luas lahan. Berdasarkan data dari Dinas Perkebunan Provinsi Jambi, luas lahan perkebunan di Provinsi Jambi terus bertambah setiap tahun. Dalam periode 2013 hingga 2015 luas lahan perkebunan di Provinsi Jambi bertambah sebesar 2,44 persen.

Selain luas lahan, tenaga kerja juga memiliki peran penting terhadap output sub sektor perkebunan di Provinsi Jambi. Tenaga kerja produktif yang merupakan pencipta kesejahteraan dan akumulasi modal. Laju akumulasi modal merupakan fungsi dari 
bagian angkatan kerja yang dipekerjakan secara produktif. Hanya tenaga kerja produktif yang dapat melakukan konsumsi produktif. Konsumsi produktif adalah konsumsi untuk memelihara dan meningkatkan kemampuan produktif masyarakat. Ini menunjukkan bahwa konsumsi produktif merupakan input yang perlu untuk memelihara tenaga kerja produktif (Jhingan, 1988).

Kualitas dan kuantitas dari tenaga kerja dalam pengelolaan lahan menentukan hasil output sub sektor perkebunan. Dilihat dari data perkembangan tenaga kerja Provinsi Jambi, jumlah tenaga kerja sub sektor provinsi Jambi mengalami peningkatan setiap tahun. Pada tahun 2013 sampai 2015 rata-rata tenaga kerja sub sektor perkebunan di Provinsi Jambi bertambah sebesar 6.944 jiwa atau meningkat sebesar satu persen.

\section{METODE}

Penelitian ini diakukan di Provinsi Jambi dengan pertimbangan bahwa Provinsi Jambi memiliki potensi alam serta areal lahan yang cukup baik untuk dikembangkannya sub sektor perkebunan di Provinsi Jambi. Data yang digunakan dalam penelitian ini adalah data sekunder dalam bentuk runtun waktu (time series) periode 2000 sampai dengan 2015. Data sekunder menurut sugiyono (2008) adalah sumber data yang tidak langsung memberi data kepada pengumpul data. Metode pengumpulan data yang digunakan dalam penelitian ini, yaitu cara riset perpustakaan (Library Research), dimana peneliti dapat mencari data yang dibutuhkan melalui sumber-sumber data sekunder yang diterbitkan oleh lembaga-lembaga pemerintah, seperti pada Badan Pusat Statistik (BPS) dan dinas perkebunan Provinsi Jambi, maupun lembaga-lembaga lain yang terkait dalam kegiatan penelitian ini. Metode analisis data yang digunakan pada penelitian ini, yaitu metode kualitatif dan kuantutatif.

\section{Analisis kualitatif}

Untuk mengetahui perkembangan tenaga kerja, luas lahan, dan PDRB sub sektor perkebunan di Provinsi Jambi periode 2000-2015, maka dapat digunakan analisis data sebagai berikut:

Dimana:

$$
L L=\frac{L_{1}-L_{t}-1}{L_{t}-1} \times 100 \%
$$

LL = Laju perkembangan luas lahan sub sektor perkebunan

LL1 = Luas lahan sub sektor perkebunan pada tahun tertentu

LLt-1 = Luas lahan sub sektor perkebunan pada tahun sebelumnya

Dimana:

$$
\mathbf{T K}=\frac{\mathbf{T K}_{1}-\mathbf{T K}_{\mathrm{t}-\mathbf{1}}}{\mathbf{T K}} \times 100 \%
$$

TK = Laju perkembangan tenaga kerja sub sektor perkebunan

TK1 = Tenaga kerja sub sektor perkebunan pada tahun tertentu

TKt-1 = Tenaga kerja sub sektor perkebunan pada tahun sebelumnya

Dimana:

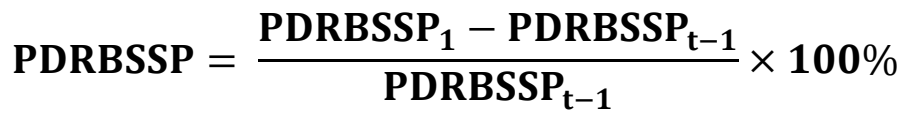

PDRBSSP = Laju perkembangan PDRB sub sektor perkebunan

PDRBSSP $1=$ PDRB sub sektor perkebunan pada tahun tertentu

PDRBSSP t -1 = PDRB sub sektor perkebunan pada tahun sebelumnya 
Untuk mengetahui dan menganalisis besarnya kontribusi sub sektor perkebunan terhadap PDRB (Produk Domestik Regional Bruto) Sektor Pertanian di Provinsi Jambi periode 2000-2015 dapat digunakan rumus sebagai berikut:

Dimana:

$$
\mathrm{K}_{\mathrm{SSP}}=\frac{\text { PDRBSSP }}{\mathrm{PDRBSP}} \times 100 \%
$$

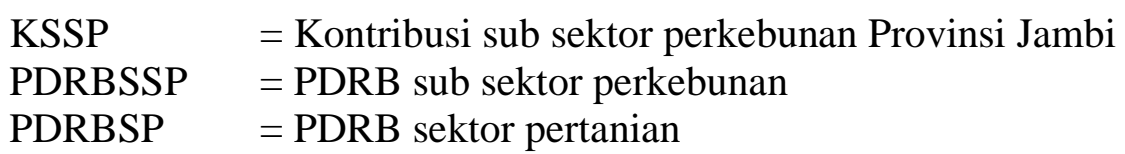

Untuk mengetahui dan menganalisis besarnya kontribusi sub sektor perkebunan terhadap PDRB (Produk Domestik Regional Bruto) Provinsi Jambi periode 2000-2015 dapat digunakan rumus sebagai berikut:

Dimana:

$$
\mathrm{K}_{\mathrm{SSP}}=\frac{\text { PDRBSSP }}{\mathrm{PDRB}} \times 100 \%
$$

KsSP = Kontribusi sub sektor perkebunan Provinsi Jambi

Nssp $=$ PDRB sub sektor perkebunan

PDRB $=$ PDRB Provinsi Jambi

\section{Analisis kuantitatif}

Analisis kuantitatif digunakan untuk melihat secara empiris sejauh mana pengaruh yang diberikan oleh Luas Lahan dan Jumlah Tenaga Kerja terhadap tingkat PDRB Sub Sektor Perkebunan. Peralatan statistik yang digunakan Persamaan Regresi Linier Berganda dengan metode OLS.

Regresi merupakan suatu alat ukur yang juga digunakan untuk mengukur ada atau tidaknya hubungan antar variabel. Adapun analisis regresi yang digunakan dalam penelitian ini terdiri atas tiga variabel (satu variabel dependen dan dua variabel independen). Menurut Sadono Sukirno (2005), fungsi produksi secara matematis dapat digambarkan sebagai berikut:

$\mathbf{Q}=\mathbf{f}(\mathbf{K}, \mathbf{L}, \mathbf{R}, \mathbf{T})$

Dimana:

$\mathrm{K}=$ Jumlah stok modal atau persediaan modal

$\mathrm{L}=$ Jumlah tenaga kerja (yang meliputi jenis tenaga kerja)

$\mathrm{T}=$ Tingkat teknologi yang digunakan

$\mathrm{R}=$ Biaya sewa lahan

$\mathrm{Q}=$ Jumlah produksi yang dihasilkan (Sukirno, 2005)

Dari persamaan di atas dijelaskan bahwa jumlah output tergantung dari kombinasi penggunaan modal, tenaga kerja, dan bahan mentah. Semakin tepat kombinasi input, semakin besar kemungkinan output dapat diproduksi secara maksimal. Salvatore (1995) menjelaskan fungsi produksi yaitu menunjukkan jumlah maksimum komoditi yang dapat diproduksi per unit waktu setiap kombinasi input alternatif, bila menggunakan teknik produksi terbaik yang tersedia.

Fungsi Produksi Cobb-Douglass

$$
Y=\alpha X 1^{b 1}, X 2^{b 2}, \ldots X n^{b n} e^{u}
$$


Dimana:

$\mathrm{Y} \quad=$ Variabel yang dijelaskan

$\mathrm{X} \quad=$ Variabel yang menjelaskan

$\mathrm{a}, \mathrm{b} \quad=$ Besaran yang akan digunakan

$\mathrm{e} \quad=$ Kesalahan (distrubance term)

Persamaan diatas sering disebut fungsi produksi Cobb-Douglas (Cobb Douglas production function). Fungsi Cobb-Douglas diperkenalkan oleh Charles W. Cobb dan Paul H. Douglass pada tahun 1920. Untuk memudahkan pendugaan terhadap persamaan di atas maka persamaan tersebut diperluas secara umum dan diubah menjadi bentuk linier dengan cara melogaritmakan persamaan tersebut. (Soekartawi, 2003), yaitu:

$\log Y=\log a+b 1 \log X 1+b 2 \log X 2+b 3 \log X 3+b 4 \log X 4+e$

Karena penyelesaian fungsi Cobb-Douglas selalu dilogaritmakan dan diubah bentuknya menjadi linier:

$$
\mathbf{Q}=\mathbf{K}^{\alpha} \cdot \mathbf{L}^{\boldsymbol{\beta}}
$$

$\log Q=\alpha \log _{K}+\beta \log _{L}+e$

$\log Q p=\beta_{0}+\log \beta_{1} L L_{t}+\log \beta_{2} T K_{t}+e$

Dimana:

$\log Q_{p}=$ Nilai PDRB output sub sektor perkebunan

$\beta_{0} \quad=$ Konstanta

$\beta_{1}, \beta_{2}=$ Koefisien regresi

LL = Luas lahan

TK $=$ Tenaga kerja sektor perkebunan

$\mathrm{t} \quad=$ Tahun tertentu

e $\quad=$ Error term

\section{HASIL DAN PEMBAHASAN}

Perkembangan luas lahan sub sektor perkebunan di Provinsi Jambi berdasarkan data Dinas Perkebunan Provinsi Jambi luas lahan sub sektor perkebunan pada tahun 2000 seluas 1.091.141 hektar. Pada tahun 2015 luas lahan sub sektor perkebunan mencapai 1.580.733 hektar. Untuk lebih jelas mengenenai perkembangan luas lahan sub sektor perkebunan di Provinsi jambi dapat dilihat pada Gambar 1.

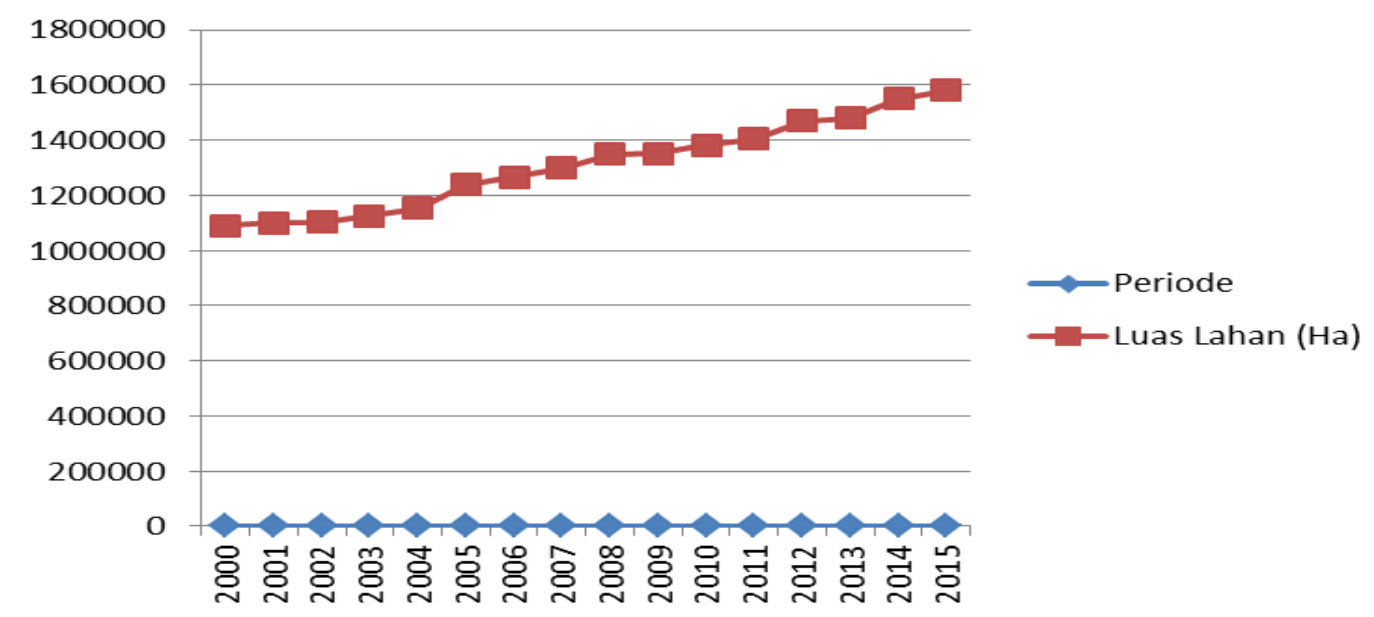

Gambar 1. Perkembangan luas lahan sub sektor perkebunan di Provinsi Jambi 
Pekembangan luas lahan sub sektor perkebunan di Provinsi Jambi periode 20002015 terus mengalami peningkatan. Rata-rata luas lahan sub sektor perkebunan di Provinsi Jambi mengalami peningkatan sebesar 2,52 persen setiap tahun. Laju perkembangan luas lahan sub sektor perkebunan tertinggi terjadi pada periode 2005, yaitu sebesar 7,52 persen. Laju perkembangan luas lahan sub sektor perkebunan tertinggi terjadi pada periode 2005, yaitu sebesar 7,52 persen. Hal ini dikarenakan pada tahun ini terjadi perluasan pembukaan lahan perkebunan terutama karet, yaitu meningkat dari 127.261 (Ha) menjadi $153.064(\mathrm{Ha})$, diikuti dengan kelapa sawit sebesar 209.446 (Ha) menjadi 253.808 (Ha). Laju perkembangan luas lahan sub sektor perkebunan terendah, yaitu pada tahun 2009 dengan persentase 0,20 persen, hal ini dikarenakan bertambahnya luas lahan tanaman rusak/tua atau adanya konveksi dari lahan perkebunan ke lahan pertambangan.

\section{Perkembangan luas lahan karet Provinsi Jambi periode 2000-2015 (Ha)}

Perkembangan luas lahan perkebunan berupa karet di Provinsi Jambi berpengaruh pada produksi dan nantinya berperan dalam peningkatan perekonomian Provinsi Jambi.. Menurut Mubyarto (1997) lahan sebagai salah satu faktor produksi yang merupakan pabriknya hasil pertanian yang mempunyai kontribusi yang besar terhadap usah tani. perkembangan luas lahan karet di Provinsi Jambi periode 2000 sampai 2015 berfluktuasi. Perkembangan luas lahan karet tertinggi, yaitu pada tahun 2005 sebesar 9,95 persen. Pada tahun ini terjadi perubahan lahan dari semak menjadi lahan perkebunan karet. Maka dari itu pada tahun 2005 terjadi perkembangan tertinggi.

Laju perkembangan terendah terjadi pada tahun 2004, yaitu sebesar -1.01 persen. Laju perkembangan luas lahan karet sebesar 1,19 persen rata-rata pertahun yang artinya terjadi pertambahan luas lahan karet rata-rata sebesar 1,19 persen atau setiap tahun terjadi penambahan luas lahan karet sebesar 1,19 persen dari total luas lahan karet sebesar 9.901.834,4 hektar.

Tabel 1. Perkembangan luas lahan karet Provinsi Jambi periode 2000-2015 (Ha)

\begin{tabular}{lcc}
\hline Tahun & Luas lahan $(\mathbf{H a})$ & Perkembangan $(\boldsymbol{\%})$ \\
\hline 2000 & 558.570 & - \\
2001 & 558.633 & 0,01 \\
2002 & 561.162 & 0,45 \\
2003 & 563.502 & 0,42 \\
2004 & 557.803 & -1.01 \\
2005 & 613.323 & 9.95 \\
2006 & 624.893 & 1,89 \\
2007 & 631.589 & 1,07 \\
2008 & 642.417 & 0,71 \\
2009 & 642.619 & 0,03 \\
2010 & 646.878 & 0,66 \\
2011 & 650.634 & 0,58 \\
2012 & 657.299 & 1,02 \\
2013 & 662.213 & 0,75 \\
2014 & 665.595 & 0,51 \\
2015 & 664.704 & $-0,13$ \\
\hline
\end{tabular}

Sumber : Dinas perkebunan Provinsi Jambi (diolah) 


\section{Perkembangan luas lahan kelapa sawit di Provinsi Jambi periode 2000-2015}

Perkembangan luas lahan sawit sebesar 3,81 persen rata-rata pertahun. Perkembangan luas lahan tertinggi yaitu pada tahun 2005 sebesar 21,18 persen sedangkan perkembangan terendah terjadi pada tahun 2004, yaitu sebesar -35,93 persen.

Tabel 2. Perkembangan luas lahan kelapa sawit di Provinsi Jambi periode 2000-2015

\begin{tabular}{lcc}
\hline Tahun & Luas $(\mathbf{H a})$ & Perkembangan $(\boldsymbol{\%})$ \\
\hline 2000 & 296.010 & - \\
2001 & 301.879 & 1,98 \\
2002 & 302.152 & 0,09 \\
2003 & $326.889,52$ & 8,19 \\
2004 & 209.446 & $-35,93$ \\
2005 & 253.808 & 21,18 \\
2006 & 268.424 & 5,76 \\
2007 & 294.851 & 9,85 \\
2008 & 316.480 & 7,34 \\
2009 & 320.554 & 1,29 \\
2010 & 341.457 & 6,52 \\
2011 & 359.791 & 5,37 \\
2012 & 395.872 & 10,03 \\
2013 & 406.949 & 2,80 \\
2014 & 436.034 & 7,15 \\
2015 & 459.960 & 5,49 \\
\hline
\end{tabular}

Sumber : Dinas perkebunan Provinsi Jambi (diolah)

\section{Perkembangan luas lahan kelapa dalam di Provinsi Jambi Periode 2000 -2015}

Perkembangan luas lahan perkebunan berupa kelapa dalam di Provinsi Jambi juga berpengaruh pada produksi dan nantinya berperan dalam peningkatan perekonomian Provinsi Jambi, hal ini dapat dilihat pada Tabel 3.

Tabel 3. Perkembangan luas lahan kelapa dalam di Provinsi Jambi Periode 2000 -2015

\begin{tabular}{llc}
\hline Tahun & Luas (Ha) & Perkembangan (\%) \\
\hline 2000 & 128.055 & - \\
2001 & 128.079 & 0,02 \\
2002 & 128.079 & 0,00 \\
2003 & 122.086 & $-4,68$ \\
2004 & 122.178 & 0,08 \\
2005 & 119.899 & $-1,87$ \\
2006 & 119.292 & $-0,51$ \\
2007 & 119.231 & $-0,05$ \\
2008 & 119.037 & $-0,16$ \\
2009 & 117.793 & $-1,05$ \\
2010 & 117.655 & $-0,12$ \\
2011 & 117.643 & $-0,01$ \\
2012 & 118.037 & 0,33 \\
2013 & 117.954 & $-0,07$ \\
2014 & 118.649 & 0,59 \\
2015 & 118.978 & 0,28 \\
\hline Rata-rata & & $\mathbf{- 0 , 4 8}$ \\
\hline
\end{tabular}

Sumber : Dinas perkebunan Provinsi Jambi (diolah) 
Luas lahan perkebunan berupa kelapa dalam kecenderungan menurun setiap tahunnya. Perkembangan luas lahan kelapa dalam di Provinsi Jambi periode 2000 sampai 2015 cenderung menurun. Perkembangan luas lahan kelapa dalam tertinggi, yaitu pada tahun 2004 sebesar 0,08 persen hal ini dikarenakan pembukaan lahan semak menjadi lahan kelapa dalam. Laju perkembangan terendah terjadi pada tahun 2003, yaitu sebesar $-4,68$ persen.

\section{Perkembangan luas lahan kelapa hybrida di Provinsi Jambi periode 2000-2015}

Perkembangan luas lahan perkebunan berupa kelapa hybrida di Provinsi Jambi juga berpengaruh pada produksi dan nantinya berperan dalam peningkatan perekonomian Provinsi Jambi. Luas lahan perkebunan berupa kelapa hybrida kecenderungan menurun setiap tahunnya.

Perkembangan luas lahan kelapa hybrida di Provinsi Jambi periode 2000 sampai 2015 cenderung menurun. Perkembangan luas lahan kelapa hybrida tertinggi, yaitu pada tahun 2012 sebesar 4,83 persen hal ini dikarenakan pembukaan lahan semak menjadi lahan kelapa hybrida.

Laju perkembangan terendah terjadi pada tahun 2006 yaitu sebesar -19,13 persen. Hal ini disebabkan oleh harga kelapa hybrida tidak menggairahkan maka petani perkebunan rakyat banyak melakukan konveksi lahan ke komoditi perkebunan lannya antara lain kelapa sawit, dan lain-lain. Laju perkembangan luas lahan kelapa hybrida sebesar -11,51 rata-rata pertahun yang artinya terjadi terjadi penurunan luas lahan kelapa dalam rata-rata sebesar $-11,51$ persen.

Tabel 4. Perkembangan luas lahan kelapa hybrida di Provinsi Jambi periode 2000-2015

\begin{tabular}{lcc}
\hline Tahun & Luas $(\mathbf{H a})$ & Perkembangan $(\boldsymbol{\%})$ \\
\hline 2000 & 7.058 & - \\
2001 & 7.111 & 0,75 \\
2002 & 7.113 & 0,03 \\
2003 & 6.789 & $-4,56$ \\
2004 & 6.174 & $-9,06$ \\
2005 & 1.270 & $-79,43$ \\
2006 & 1.027 & $-19,13$ \\
2007 & 877 & $-14,61$ \\
2008 & 771 & $-12,09$ \\
2009 & 764 & $-0,91$ \\
2010 & 751 & $-1,7$ \\
2011 & 745 & $-0,80$ \\
2012 & 781 & 4,83 \\
2013 & 711 & $-8,96$ \\
2014 & 597 & $-16,03$ \\
2015 & 531 & $-11,06$ \\
\hline
\end{tabular}

Sumber: Dinas perkebunan Provinsi Jambi (diolah)

\section{Perkembangan luas lahan kopi di Provinsi Jambi periode 2000 - 2015}

Perkembangan luas lahan kopi di Provinsi Jambi periode 2000 sampai 2015 cenderung menurun. Perkembangan luas lahan kopi Provinsi Jambi dapat dilihat pada Tabel 5. 
Tabel 5. Perkembangan luas lahan kopi di Provinsi Jambi periode 2000-2015

\begin{tabular}{lcc} 
Tahun & Luas $(\mathbf{H a})$ & Perkembangan $(\boldsymbol{\%})$ \\
\hline 2000 & 28.755 & - \\
2001 & 28.594 & -056 \\
2002 & 28.532 & $-0,22$ \\
2003 & 28.400 & $-0,46$ \\
2004 & 24.372 & $-14,18$ \\
2005 & 24.638 & 1,09 \\
2006 & 24.458 & $-0,73$ \\
2007 & 24.217 & $-0,99$ \\
2008 & 24.365 & 0,61 \\
2009 & 24.918 & 2,27 \\
2010 & 25.007 & 0,36 \\
2011 & 25.283 & 1,10 \\
2012 & 25.749 & 1,84 \\
2013 & 25.935 & 0,72 \\
2014 & 26.094 & 0,61 \\
2015 & 26.286 & 0,74 \\
\hline
\end{tabular}

Sumber : Dinas perkebunan Provinsi Jambi (diolah)

Dari Tabel.5 dapat kita dilihat bahwa perkembangan luas lahan kopi tertinggi, yaitu pada tahun 2009 sebesar 2,27 persen. Sedangkan perkembangan terendah terjadi pada tahun 2004, yaitu sebesar $-14,18$ persen. Laju perkembangan luas lahan kopi sebesar -0,52 rata-rata pertahun.

Laju perkembangan luas lahan kopi sebesar -0,52 rata-rata pertahun yang artinya terjadi terjadi penurunan luas lahan kopi rata-rata sebesar -0,52 persen atau setiap tahun terjadi penurunan luas lahan kopi sebesar $-0,52$ persen dari total luas lahan kopi sebesar 415.603 hektar.

\section{Perkembangan luas lahan kakao di Provinsi Jambi periode 2000-2015}

Perkembangan luas lahan perkebunan berupa kakao di Provinsi Jambi berpengaruh pada produksi dan nantinya berperan dalam peningkatan perekonomian Provinsi Jambi. Menurut Mubyarto (1997) lahan sebagai salah satu faktor produksi yang merupakan pabriknya hasil pertanian yang mempunyai kontribusi yang besar terhadap usah tani.

Perkembangan luas lahan kakao di Provinsi Jambi periode 2000 sampai 2015 berfluktuasi. Perkembangan luas lahan kakao tertinggi, yaitu pada tahun 2010 sebesar 46,37 persen peningkatan ini terjadi karena pada tahun ini beberapa petani mencoba untuk membudidayakan komoditi kakao. Adanya konversi lahan dari perkebunan kopi menjadi perkebunan kakao hal ini terlihat dari perkembangan luas lahan kopi sebesar 0,36 persen.

Pada tahun 2013 sampai 2015 tidak terjadi perubahan pada luas lahan atau dapat dikatakan perkembangannya adalah 0 . Tidak terjadinya perkembangan pada luas lahan kopi ini dikarenakan hasil yang berupa pendapatan yang didapat oleh produksi kopi ini kurang memuaskan maka para petani tidak tertarik untuk melakukan perluasan areal kecuali hanya memeliharaan tanaman yang sudah ada. 
Tabel 6. Perkembangan luas lahan kakao di Provinsi Jambi periode 2000-2015

\begin{tabular}{lcc}
\hline Tahun & Jumlah (Ha) & Perkembangan (\%) \\
\hline 2000 & 4.834 & - \\
2001 & 2.965 & $-38,66$ \\
2002 & 2.971 & 0,20 \\
2003 & $1.790,5$ & $-39,73$ \\
2004 & 1.354 & $-24,38$ \\
2005 & 1.220 & $-9,90$ \\
2006 & 1.417 & 16,15 \\
2007 & 1.420 & 0,21 \\
2008 & 1.319 & $-7,11$ \\
2009 & 1.324 & 0,38 \\
2010 & 1.938 & 46,37 \\
2011 & 1.986 & 2,48 \\
2012 & 2.040 & 2,72 \\
2013 & 2.082 & 2,06 \\
2014 & 2.220 & 6,63 \\
2015 & 2.270 & 2,25 \\
\hline
\end{tabular}

Sumber : Dinas perkebunan Provinsi Jambi (diolah)

\section{Perkembangan luas lahan pinang di Provinsi Jambi periode 2000-2015}

Perkembangan luas lahan pinang Provinsi Jambi periode 2000 sampai 2015 berfluktuasi. Perkembangan luas lahan perkebunan berupa pinang di Provinsi Jambi juga berpengaruh pada produksi dan nantinya berperan dalam peningkatan perekonomian Provinsi Jambi. Adapun perkembangan luas lahan pinang dapat dilihat pada Tabel 7.

Tabel 7. Perkembangan luas lahan pinang di Provinsi Jambi periode 2000-2015

\begin{tabular}{lcc}
\hline Tahun & Luas $\mathbf{( H a )}$ & Perkembangan $(\%)$ \\
\hline 2000 & 1.882 & - \\
2001 & 5.367 & 185,18 \\
2002 & 5.420 & 0,99 \\
2003 & $9.905,5$ & 82,76 \\
2004 & 6.447 & $-34,91$ \\
2005 & 9.980 & 54,80 \\
2006 & 10.178 & 1,98 \\
2007 & 12.207 & 19,94 \\
2008 & 19.672 & 61,15 \\
2009 & 17.977 & $-8,62$ \\
2010 & 18.062 & 0,47 \\
2011 & 18.204 & 0,79 \\
2012 & 18.637 & 2,38 \\
2013 & 18.715 & 0,42 \\
2014 & 18.899 & 0,98 \\
2015 & 19.696 & 4,22 \\
\hline & Rata-rata & $\mathbf{2 4 , 8 3}$ \\
\hline
\end{tabular}

Sumber : Dinas perkebunan Provinsi Jambi (diolah) 
Perkembangan luas lahan pinang tertinggi yaitu pada tahun 2001 sebesar 185,18 persen. Laju perkembangan terendah terjadi pada tahun 2004 yaitu sebesar -34,91 persen. Laju perkembangan luas lahan pinang sebesar 24,83 rata-rata pertahun.

Perkembangan luas lahan kulit kayu manis di Provinsi Jambi periode 2000-2015

Perkembangan luas lahan kulit kayu manis Provinsi Jambi periode 2000 sampai 2015 cenderung menurun, hal ini dapat dilihat pada Tabel 8.

Tabel 8. Perkembangan luas lahan kulit kayu manis di Provinsi Jambi

\begin{tabular}{lcc}
\hline Tahun & Luas $\mathbf{( H a )}$ & Perkembangan $\mathbf{( \% )}$ \\
\hline 2000 & 60.776 & - \\
2001 & 61.769 & 1,63 \\
2002 & 62.128 & 0,58 \\
2003 & $59.845,4$ & $-3,67$ \\
2004 & 54.630 & $-8,71$ \\
2005 & 50.402 & $-7,74$ \\
2006 & 49.106 & $-2,57$ \\
2007 & 47.620 & $-3,03$ \\
2008 & 47.237 & $-0,80$ \\
2009 & 47.447 & 0,44 \\
2010 & 47.612 & 0,35 \\
2011 & 47.213 & $-0,84$ \\
2012 & 47.192 & $-0,04$ \\
2013 & 46.741 & $-0,96$ \\
2014 & 46.289 & $-0,97$ \\
2015 & 46.183 & $-0,23$ \\
\hline
\end{tabular}

Sumber : Dinas perkebunan Provinsi Jambi (diolah)

Perkembangan luas lahan kulit kayu manis tertinggi, yaitu pada tahun 2001 sebesar 1,63 persen. Laju perkembangan terendah terjadi pada tahun 2004, yaitu sebesar $-8,71$ persen. Laju perkembangan luas lahan kulit kayu manis sebesar $-1,77$ rata-rata pertahun.

\section{Perkembangan luas lahan lada di Provinsi Jambi periode 2000-2015}

Perkembangan luas lahan kakao di Provinsi Jambi periode 2000 sampai 2015 berfluktuasi. Perkembangan luas lahan lada tertinggi, yaitu pada tahun 2010 sebesar 46,37 persen peningkatan ini terjadi karena pada tahun ini beberapa petani mencoba untuk membudidayakan komoditi kakao. Adanya konversi lahan dari perkebunan kopi menjadi perkebunan kakao hal ini terlihat dari perkembangan luas lahan kopi sebesar 0,36 persen.

Pada tahun 2013 sampai 2015 tidak terjadi perubahan pada luas lahan atau dapat dikatakan perkembangannya adalah 0 . Tidak terjadinya perkembangan pada luas lahan kopi ini dikarenakan hasil yang berupa pendapatan yang didapat oleh produksi kopi ini kurang memuaskan maka para petani tidak tertarik untuk melakukan perluasan areal kecuali hanya memeliharaan tanaman yang sudah ada.

Perkembangan luas lahan lada di Provinsi Jambi periode 2000 sampai 2015 cenderng menurun. Perkembangan luas lahan lada tertinggi, yaitu pada tahun 2008 sebesar 154.35 persen peningkatan ini terjadi karena pada tahun ini beberapa petani 
mencoba untuk membudidayakan komoditi lada. Laju perkembangan terendah terjadi pada tahun 2003, yaitu sebesar -37.12 persen. Hal ini dapat dilihat pada Tabel 9 .

Tabel 9. Perkembangan luas lahan lada di Provinsi Jambi periode 2000-2015

\begin{tabular}{lcc}
\hline Tahun & Luas (Ha) & Perkembangan (\%) \\
\hline 2000 & 262 & - \\
2001 & 217 & $-17,18$ \\
2002 & 215 & $-0,92$ \\
2003 & 135.2 & $-37,12$ \\
2004 & 115 & $-14,94$ \\
2005 & 114 & $-0,87$ \\
2006 & 86 & $-24,56$ \\
2007 & 92 & 6,98 \\
2008 & 234 & 154,35 \\
2009 & 233 & $-0,43$ \\
2010 & 234 & 0,43 \\
2011 & 236 & 0,85 \\
2012 & 225 & $-4,66$ \\
2013 & 151 & $-32,89$ \\
2014 & 115 & $-23,84$ \\
2015 & 124 & 7,83 \\
\hline & Rata-rata & $\mathbf{0 , 8 7}$ \\
\hline
\end{tabular}

Sumber : Dinas perkebunan Provinsi Jambi (diolah)

\section{Perkembangan jumlah tenaga kerja sub sektor perkebunan Provinsi Jambi}

Perkembangan jumlah tenaga kerja sub sektor perkebunan di Provinsi Jambi terus mengalami peningkatan selama periode 2000 sampai 2015. Laju perkembangan luas lahan sub sektor perkebunan tertinggi terjadi pada periode 2011, yaitu sebesar 14,17 persen. Sedangkan perkembangan terendah terjadi pada tahun 2009 , yaitu sebesar 0,16 persen. Untuk lebih jelas mengenenai perkembangan luas lahan sub sektor perkebunan di Provinsi jambi dapat dilihat pada Gambar 2 berikut ini.



Gambar 2. Perkembangan tenaga kerja sub sektor perkebunan di Provinsi Jambi

\section{Perkembangan PDRB sub sektor perkebunan di Provinsi Jambi}

Berdasarkan data diatas PDRB sub sektor perkebunan di Provinsi Jambi terus mengalami peningkatan selama periode. Rata-rata PDRB sub sektor perkebunan di Provinsi Jambi mengalami penigkatan sebesar 7,84 persen setiap tahun. Peningkatan tertinggi terjadi pada periode 2006, yaitu sebesar 25,20persen. Sedangkan peningkatan 
terendah terjadi pada tahun 2001, yaitu sebesar 2,89 persen. Untuk lebih jelas mengenenai perkembangan PDRB sub sektor perkebunan di Provinsi jambi dapat dilihat pada grafik berikut ini.



Gambar 3. Perkembangan PDRB sub sektor perkebunan di Provinsi Jambi

\section{Kontribusi PDRB sub sektor perkebunan terhadap PDRB sektor pertanian}

Adapun kontribusi sub sektor perkebunan terhadap sektor pertanian Provinsi Jambi adalah sebagai berikut:

Tabel 10. Kontribusi sub sektor perkebunan terhadap sektor pertanian di Provinsi Jambi

\begin{tabular}{cccc}
\hline Periode & $\begin{array}{c}\text { PDRB sub sektor } \\
\text { perkebunan (Juta } \\
\text { Rupiah) }\end{array}$ & $\begin{array}{c}\text { PDRB sektor } \\
\text { pertanian (Juta } \\
\text { Rupiah) }\end{array}$ & $\begin{array}{c}\text { Kontribusi sub sektor } \\
\text { perkebunan } \\
\text { terhadap sektor } \\
\text { pertanian (\%) }\end{array}$ \\
\hline 2000 & 1.190 .525 & 3.168 .557 & 37,57 \\
2001 & 1.224 .954 & 3.286 .182 & 37,28 \\
2002 & 1.331 .451 & 3.445 .511 & 38,64 \\
2003 & 1.409 .277 & 3.568 .015 & 39,50 \\
2004 & 1.516 .507 & 3.749 .356 & 40,45 \\
2005 & 1.588 .829 & 3.922 .075 & 40,51 \\
2006 & 1.989 .267 & 4.366 .677 & 45,56 \\
2007 & 2.072 .373 & 4.566 .134 & 45,39 \\
2008 & 2.197 .097 & 4.827 .241 & 45,51 \\
2009 & 2.368 .323 & 5.148 .546 & 46,00 \\
2010 & 2.531 .684 & 5.412 .392 & 46,78 \\
2011 & 2.722 .741 & 5.742 .052 & 47,42 \\
2012 & 2.948 .764 & 6.178 .408 & 47,73 \\
2013 & 3.186 .854 & 6.636 .219 & 48,02 \\
2014 & 3.409 .598 & 7.134 .614 & 47,79 \\
2015 & 3.642 .385 & 7.517 .274 & 48,45 \\
\hline & Rata-rata & & $\mathbf{4 3 , 9 1}$ \\
\hline
\end{tabular}

Sumber : Badan Pusat Statistik Provinsi Jambi (diolah)

Pada Tabel 10 dapat kita lihat bahwa kontribusi PDRB sub sektor perkebunan Provinsi Jambi selama periode 2000-2015 terhadap PDRB sektor pertanian Provinsi Jambi sebesar 43,91 persen. Kontribusi tertinggi sub sektor perkebunan Provinsi Jambi 
terhadap PDRB sektor pertanian Provinsi Jambi terjadi pada tahun 2015 yaitu sebesar 48,45 persen. Sedangkan kontribusi terkecil PDRB sub sektor perkebunan terhadap PDRB sektor pertanian Provinsi Jambi yaitu tahun 2001 dengan kontribusi sebesar 37,28 persen.

\section{Kontribusi PDRB sub sektor perkebunan terhadap PDRB Provimsi Jambi}

Kontribusi sub sektor perkebunan terhadap sektor pertanian menggambarkan peranan sub sektor perkebunan dalam pembentukan PDRB sektor pertanian. Sub sektor perkebunan memberikan kontribusi cukup besar bagi PDRB Provinsi Jambi. Berikut ini data kontribusi sub sektor perkebunan terhadap PDRB Provinsi Jambi. Pada Tabel 5.13 dapat kita lihat bahwa kontribusi PDRB sub sektor perkebunan Provinsi Jambi selama periode 2000-2015 terhadap PDRB Provinsi Jambi sebesar 14,04 persen. Kontribusi tertinggi sub sektor perkebunan Provinsi Jambi terhadap PDRB Provinsi Jambi terjadi pada tahun 2015, yaitu sebesar 15,93 persen. Sedangkan terendah, yaitu tahun 2001 sebesar 11,18 persen.

Tabel 11. Kontribusi PDRB sub sektor perkebunan terhadap PDRB Provinsi Jambi

\begin{tabular}{cccc}
\hline Periode & $\begin{array}{c}\text { PDRBSSP } \\
\text { (Juta Rupiah) }\end{array}$ & $\begin{array}{c}\text { PDRB Provinsi } \\
\text { Jambi (Juta Rupiah) }\end{array}$ & $\begin{array}{c}\text { Kontribusi sub sektor } \\
\text { perkebunan } \\
\text { terhadap PDRB Provinsi } \\
\text { Jambi (\%) }\end{array}$ \\
\hline 2000 & 1.190 .525 & 9.262 .276 & 12,85 \\
2001 & 1.224 .954 & 10.957 .644 & 11,18 \\
2002 & 1.331 .451 & 10.803 .423 & 12,32 \\
2003 & 1.409 .277 & 11.343 .280 & 12,42 \\
2004 & 1.516 .507 & 11.953 .885 & 12,69 \\
2005 & 1.588 .829 & 12.619 .972 & 12,59 \\
2006 & 1.989 .267 & 13.363 .620 & 14,89 \\
2007 & 2.072 .373 & 14.275 .161 & 14,52 \\
2008 & 2.197 .097 & 15.298 .000 & 14,36 \\
2009 & 2.368 .323 & 16.272 .000 & 14,55 \\
2010 & 2.531 .684 & 16.839 .144 & 15,03 \\
2011 & 2.722 .741 & 18.042 .724 & 15,09 \\
2012 & 2.948 .764 & 19.321 .463 & 15,26 \\
2013 & 3.186 .854 & 20.644 .013 & 15,44 \\
2014 & 3.409 .598 & 21.870 .411 & 15,59 \\
2015 & 3.642 .385 & 22.871 .914 & 15,93 \\
\hline
\end{tabular}

Sumber: Badan Pusat Statistik Provinsi Jambi(diolah)

Analisis pengaruh luas lahan dan tenaga kerja terhadap output sub sektor perkebunan Provinsi Jambi.

Dalam penelitian ini akan dijelaskan hasil-hasil pemikiran antara faktor-faktor yang mempengaruhi output sub sektor perkebunan di Provinsi Jambi. Adapun faktorfaktor yang mempengaruhi output sub sektor perkebunan di Provinsi Jambi, yaitu luas tanaman perkebunan/luas lahan dan jumlah tenaga kerja sektor perkebunan. Metode regresi berganda digunakan dalam penelitian ini untuk membuktikan dihipotesis mengenai hubungan antar variabel devenden dan variabel independen. 
Tabel 12. Hasil regresi

\begin{tabular}{lllll}
\hline Variable & Coefficient & Std. Error & t-Statistic & Prob. \\
\hline \hline C & -11.17515 & 0.825325 & -13.54030 & 0.0000 \\
LOGLL & 2.488961 & 0.476004 & 5.228869 & 0.0002 \\
LOGTK & 0.397616 & 0.400619 & 0.992505 & 0.3391 \\
& & & & \\
\hline \hline R-squared & 0.985268 & Mean dependent var & 6.316004 \\
Adjusted R-squared & 0.983001 & S.D. dependent var & 0.162856 \\
S.E. of regression & 0.021233 & Akaike info criterion & -4.699155 \\
Sum squared resid & 0.005861 & Schwarz criterion & -4.554295 \\
Log likelihood & 40.59324 & Hannan-Quinn criter. & -4.691737 \\
F-statistic & 434.7065 & Durbin-Watson stat & 2.495882 \\
Prob (F-statistic) & 0.000000 & & \\
\hline Sumber: Data ditah & 2018 & &
\end{tabular}

Sumber: Data diolah, 2018

Dari hasil analisis Tabel 12 dapat dilhat besarnya koefisien luas lahan sub perkebunan sebesar 2.488961. Sedangkan koefisien jumlah tenaga kerja sub sektor perkebunan sebesar 0.397616. Dilihat dari analisis regresi masing-masing variabel independen hanya satu yang signifikan terhadap PDRB sub sektor perkebunan Provinsi Jambi, yaitu luas lahan. Hal ini menunjukkan bahwa faktor-faktor yang mempengaruhi PDRB sub sektor perkebunan Provinsi Jambi, yaitu luas lahan dengan koefisien sebesar 2.488961 dengan probabilitas sebesar $0,0002<\alpha(0,05)$ yang berarti bahwa luas lahan merupakan salah satu faktor-faktor yang mempengaruhi PDRB sub setor perkebunan Provinsi Jambi. Sedangkan tenaga kerja tidak berpengaruh signifikan terhadap PDRB sub sektor perkebunan Provinsi Jambi. Metode OLS dalam regresi berganda bertujuan untuk dapat meminimumkan residual kuadrat. Metode yang digunakan dalam perhitungan regresi berganda dengan program, yaitu sebagai berikut:

\section{$\log Q p=-11.17515+2.488961$ LOGLL + 0.397616LOGTK + e}

Nilai $\alpha=-11.17515$, artinya apabila luas lahan dan tenaga kerja sebesar 0 , maka PDRB sub sektor perkebunan sebesar -11.17515 tetapi tidak signifikan pada alpha sebesar $5 \%$. Kemudian nilai $\beta 1=2.488961$, artinya dengan asumsi luas lahan tetap, maka setiap peningkatan luas lahan sebesar $1 \%$ akan menaikkan PDRB sub sektor perkebunan sebesar $2.488961 \%$. Nilai $\beta 2=0.39761$, artinya dengan asumsi tenaga kerja tetap, maka setiap peningkatan luas lahan sebesar $1 \%$ akan menaikkan PDRB sub sektor perkebunan sebesar $0.397616 \%$.

\section{KESIMPULAN DAN SARAN}

\section{Kesimpulan}

Perkembangan luas lahan, tenaga kerja dan PDRB sub sektor perkebunan Provinsi Jambi periode 2000-2015 terus mengalami peningkatan setiap tahunnya. Rata-rata perkembangan luas lahan sub sektor perkebunan Provinsi Jambi adalah sebesar 2,52\%. Tenaga kerja sub sektor perkebunan mengalami perkembangan setiap tahunnya dengan rata-rata perkembangan sebesar $2,74 \%$. PDRB sub sektor perkebunan mengalami perkembangan dengan rata-rata sebesar 7,84\%.

Kontribusi PDRB sub sektor perkebunan terhadap PDRB pertanian terus meningkat dengan rata-rata peningkatan sebesar 43,91\%. Sedangkan kontribusi PDRB 
sub sektor perkebunan terhadap PDRB Provinsi Jambi juga terus meningkat setiap tahunnya dengan rata-rata peningkatan sebesar 14,04\%. Berdasarkan hasil perhitungan regresi, variabel luas lahan dan jumlah tenaga kerja secara bersama-sama atau simultan mempengaruhi PDRB sub sektor perkebunan Provinsi Jambi. Secara parsial variabel luas lahan berpengaruh positif dan signifikan terhadap PDRB sub sektor perkebunan Provinsi Jambi. Sedangkan tenaga kerja tidak berpengaruh signifikan terhadap PDRB sub sektor perkebunan Provinsi Jambi.

\section{Saran}

Bagi pihak yang ingin melakukan penelitian selanjutnya tentang sub sektor perkebunan bisa mencoba menggunakan variabel lain yang belum dijelaskan pada penelitian ini dan penggunaan pendekatan lain untuk mendapatkan hasil yang lebih baik. Bagi pemerintah daerah Provinsi Jambi sebaiknya meningkatkan kerjasama dengan masyarakat untuk mengoptimalkan segala potensi pada sub sektor perkebunan Provinsi Jambi guna memaksimalkan output sub sektor perkebunan di Provinsi Jambi.

\section{DAFTAR PUSTAKA}

Adiwilaga, Anwas. (1992). Ilmu usaha tani: Cetakan II. Alumni: Bandung.

Badan Pusat Statistik Indonesia. (2011). Luas tanaman perkebunan besar menurut jenis tanaman di Indonesia. BPS Indonesia: Jakarta.

D Hastuti, A Delis, R Rosmeli . (2018).Pengembangan Komoditas Kelapa Sawit Dan Karet Serta Dampaknya Terhadap Pendapatan Petani di Kecamatan Pelepat Ilir, Jurnal Sains Sosio Humaniora 2 (2), 92-104

Jhingan. (1988). Ekonomi pembangunan dan perencanaan. Diterjemahkan oleh D. Guritno. Rajawali Pers: Jakarta.

Jhingan. (1993). Ekonomi pembangunan dan perencanaan. Rajawali Pers: Jakarta.

L Istiqomah, E Umiyati, H Hardiani.(2018).Pengaruh modal dan tenaga kerja terhadap nilai produksi industri pisang salai di Desa Purwobakti Kecamatan Bathin III Kabupaten Bungo, e-Jurnal Ekonomi Sumberdaya dan Lingkungan 7 (1), 43-55

Mubyarto. (1997). Pengantar ekonomi pertanian. Intermasa: Jakarta.

Salvator, Dominick. (1995). Teori mikroekonomi. Erlangga: Jakarta.

Soekartawi. (2003). Teori ekonomi produksi dengan pokok bahasan analisis fungsi Coob-Douglas. PT.Raja Grafindo Persada: Jakarta.

Soetrisno, L. (1999). Kelapa sawit: kajian sosial ekonomi. Aditiya P3Pk UGM: Yogyakarta.

Sugiyono. (2008). Metode penelitian kuantitatif kuantitatif dan R\&D. Alfabeta: Bandung.

Sukirno, Sadono. (2005). Mikro ekonomi, teori pengantar. Raja Grafindo Persada: Jakarta. 